\title{
Radiosonde Penetration of an Undilute Cumulonimbus Anvil
}

\author{
LANCE F. BOSART \\ Department of Atmospheric Science, State University of New York at Albany, Albany, New York \\ JOHN W. NIELSEN \\ Department of Meteorology, Texas A \& M University, College Station, Texas
}

(Manuscript received 30 September 1992, in final form 9 December 1992)

\begin{abstract}
An example is presented of the serendipitous radiosonde penetration through the western edge of a rapidly growing undilute cumulonimbus anvil above $200 \mathrm{mb}$ by an operationally released radiosonde balloon. The sounding is supportive of deep convection and contains a stable layer $\left(13^{\circ} \mathrm{C}\right.$ potential temperature increase) from 210 to $185 \mathrm{mb}$ with a quasi-adiabatic mixed layer from there to $135 \mathrm{mb}$. The $185-135-\mathrm{mb}$ layer has a wet-bulb potential temperature of $24^{\circ} \mathrm{C}$ which agrees to within $1{ }^{\circ} \mathrm{C}$ of the subcloud-layer wet-bulb potential temperature. The wind perturbation of approximately $30 \mathrm{~m} \mathrm{~s}^{-1}$ within the mixed layer is larger than, but consistent with, relative outflow velocities estimated from satellite imagery and density current theory. Downstream soundings through decaying anvil debris $12 \mathrm{~h}$ later still show evidence of the initial convective thermal perturbation even as the tropopause attempts to reform in the vicinity of $200 \mathrm{mb}$.

Implications for the tropospheric-stratospheric exchange of water vapor and the measurement of water vapor at cold temperatures are discussed. The present operational practice of not reporting moisture data at high levels in the troposphere when the ambient temperature is less than $-40^{\circ} \mathrm{C}$ deprives users of potentially useful moisture information.
\end{abstract}

\section{Introduction}

Cumulus clouds are manifestations of a complex variety of thermodynamical and dynamical processes both internal and external to the cloud. Entrainment of environmental air as rising cloud parcels encounter a progressively drier environment (Stommel 1947; Austin and Fleischer 1948) acts to overcome the lift provided by undilute moist adiabatic ascent that is assumed by simple parcel theory. In a series of landmark papers, Riehl et al. (1951) and Riehl and Malkus (1957, 1958) first demonstrated the importance of deep cumulus convection to the maintenance of the heat and moisture budget of the intertropical convergence zone (ITCZ). These authors found that the only way to satisfy these budgets was to require that the bulk of the equatorward converging trade-wind air in both hemispheres be uplifted in deep undilute ascent from cloud base to the upper troposphere associated with cumulonimbus clouds in disturbances along the ITCZ. A crucial aspect of their findings, reaffirmed in Riehl (1979) and Riehl and Simpson (1979), was that the width of the undilute updraft cores be sufficiently great to protect them from the ravages of entrainment.

Corresponding author address: Dr. Lance F. Bosart, Department of Science, ES.227, State University of New York at Albany, 1400 Washington Ave., Albany, NY 12222.
Newton (1966), in a study of organized severe convective systems in strongly sheared environments in midlatitudes, showed that the storms tilted upshear in direct proportion to the magnitude of the undilute ascent in the updraft cores. The expanding anvils consisted of air that had never left the troposphere and formerly undilute air that had reached into the lower stratosphere and then descended because of the entrainment of drier air from outside the previously protected updraft cores.

Radiosonde penetration of undilute updraft cores is comparatively rare. A noteworthy recent exception was the launch of a mobile sounding into a dryline storm as described by Bluestein et al. (1988). The sounding, which penetrated the storm wall cloud, indicated a nearly pseudo-moist-adiabatic lapse rate, a temperature excess of $10^{\circ} \mathrm{C}$ at $500 \mathrm{mb}$ over the environment, and an updraft speed of close to $50 \mathrm{~m} \mathrm{~s}^{-1}$ approximately 6 $\mathrm{km}$ above the ground. These values are close to expectation from undilute buoyant ascent. Four other less dramatic ascents through undilute updraft cores have been analyzed by Davies-Jones (1974).

Given the importance of deep, undilute ascent in cumulonimbus updrafts to the heat, moisture, and momentum budgets of the atmosphere, the purpose of this paper is to take advantage of the serendipitous radiosonde penetration of an undilute anvil that contained formerly subcloud air. We will link this obser- 
vation to the kinematics of cirrus outflow and lowerstratospheric desiccation. The event in question occurred along the coast of the Gulf of Mexico on 26 April 1991 and will be documented by means of conventional data in conjunction with satellite imagery and cloud-to-ground lightning maps. For reference, Fig. 1 shows the location of all stations mentioned in the text.

\section{The convective event of 26 April 1991}

Surface sectional maps for 0900 and 1200 UTC 26 April 1991 are presented in Fig. 2. The 0900 UTC map shows the existence of a broad, moist south-southeast flow impinging on the coast from the Gulf of Mexico. An estimated average temperature (dewpoint) of $23^{\circ} \mathrm{C}$ $\left(22^{\circ} \mathrm{C}\right.$ ) (equivalent potential temperature of approximately $344 \mathrm{~K}$ ) is found within the onshore flow. A line of convergence, here interpreted as a weak warm-frontal boundary, separates the more southerly onshore flow along the coast from a more easterly flow in Louisiana and eastern Texas. Fog and drizzle are found north of the boundary. The operational National Weather Service (NWS) manually digitized radar (MDR) map for this time (Fig. 3a) indicates that the strongest convective activity is over southern Louisiana near the frontal boundary.

Within the next $3 \mathrm{~h}$, widespread intense convection has developed along the Gulf coast. A line of VIP (video integrating processor) level-5 echoes (Fig. 3b) extends from southwestern Louisiana into the northern Gulf of Mexico, with echo tops as high as $19.8 \mathrm{~km}$. The surface pattern at 1200 UTC (Fig. 2b) is relatively unchanged except that the surface boundary over southeastern Louisiana has strengthened and several stations are reporting light to heavy thunderstorms. The temperature (dewpoint) of the moist southerly flow over the extreme northern Gulf of Mexico are now estimated to average $25^{\circ} \mathrm{C}\left(24^{\circ} \mathrm{C}\right.$ ) (equivalent potential temperature of approximately $353 \mathrm{~K}$ ).

The warm-frontal boundary proceeded to shift slowly northward and by 0000 UTC 27 April (not

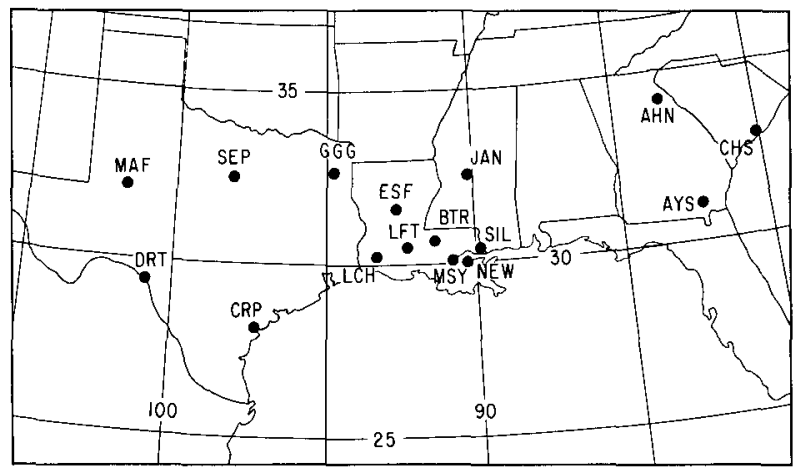

FIG. 1. Three-letter station identifier map. shown ) it lay from the Louisiana-Arkansas border eastsoutheastward to extreme northern Florida. Showers and thunderstorms persisted along and to the north of the boundary in an area of deep warm-air advection.

Infrared satellite imagery and cloud-to-ground lightning maps (Orville et al. 1983) for selected time periods near 1200 UTC 26 April are shown in Figs. 4 and 5, respectively. Noteworthy is the explosive growth of high, cold cloud tops beginning shortly before 1000 UTC (Fig. 4a) as convection erupts along the southern Louisiana coast eastward into the northern Gulf of Mexico. By 1400 UTC (Fig. 4d) the high, cold cloud tops have expanded well downwind as well as northward and southward from an apparent source in southeastern Louisiana.

The hourly lightning maps provide further evidence of the explosive growth of deep convection over extreme southern Louisiana. A total of 122 cloud-toground flashes were recorded in the hour ending 0900 UTC (not shown), increasing to 336 flashes in the following hour (Fig. 5a). Flashes were clustered south of Lafayette (LFT) and to the south of the New Orleans area (MSY, NEW). Between 1000 and 1100 UTC (Fig. $5 b)$ the number of lightning flashes more than triples to 1176 and they are arranged in distinct clusters with the greatest concentration along the western Louisiana coast (confirmed by the LFT 1050 UTC observation of frequent lightning in clouds to the south; not shown ). For the hour ending 1200 UTC (Fig. 5c) the recorded flashes total 1510 and they remain concentrated in distinct clusters beginning approximately $50 \mathrm{~km}$ to the east of Lake Charles, Louisiana, ( $\mathrm{LCH}$ ). In the following hour (Fig. 5d) the cloud-to-ground lightning activity continues to move slowly eastward. The comparatively few positive flashes ("+" symbols) in the 2 -h period ending 1300 UTC tend to be displaced downshear from the more abundant negative flashes as discussed by, for example, Rust et al. (1981) and Stolzenburg (1990).

\section{Rawinsonde observations}

The large-scale $200-\mathrm{mb}$ manual analyses for 0000 and 1200 UTC 26 April 1991 are depicted in Figs. 6a and $6 \mathrm{~b}$. Noteworthy is the broad west-southwesterly to westerly flow of $35-50 \mathrm{~m} \mathrm{~s}^{-1}$ extending from Texas to the Carolinas at both time periods in conjunction with the subtropical jet. Likewise, temperatures in this region are quasi-uniform with most readings in the $-57^{\circ}$ to $-60^{\circ} \mathrm{C}$ range. The lack of a significant short wave at upper levels is consistent with the character of the coastal convection, which had for several days repeatedly regenerated during the early morning hours.

The most anomalous temperature at $200 \mathrm{mb}$ is found at LCH (72240). The reported temperature of $-54.5^{\circ} \mathrm{C}$ at 1200 UTC (Fig. 6b) appears to be warmer by $2^{\circ}-4^{\circ} \mathrm{C}$ than would be expected, given nearby ob- 

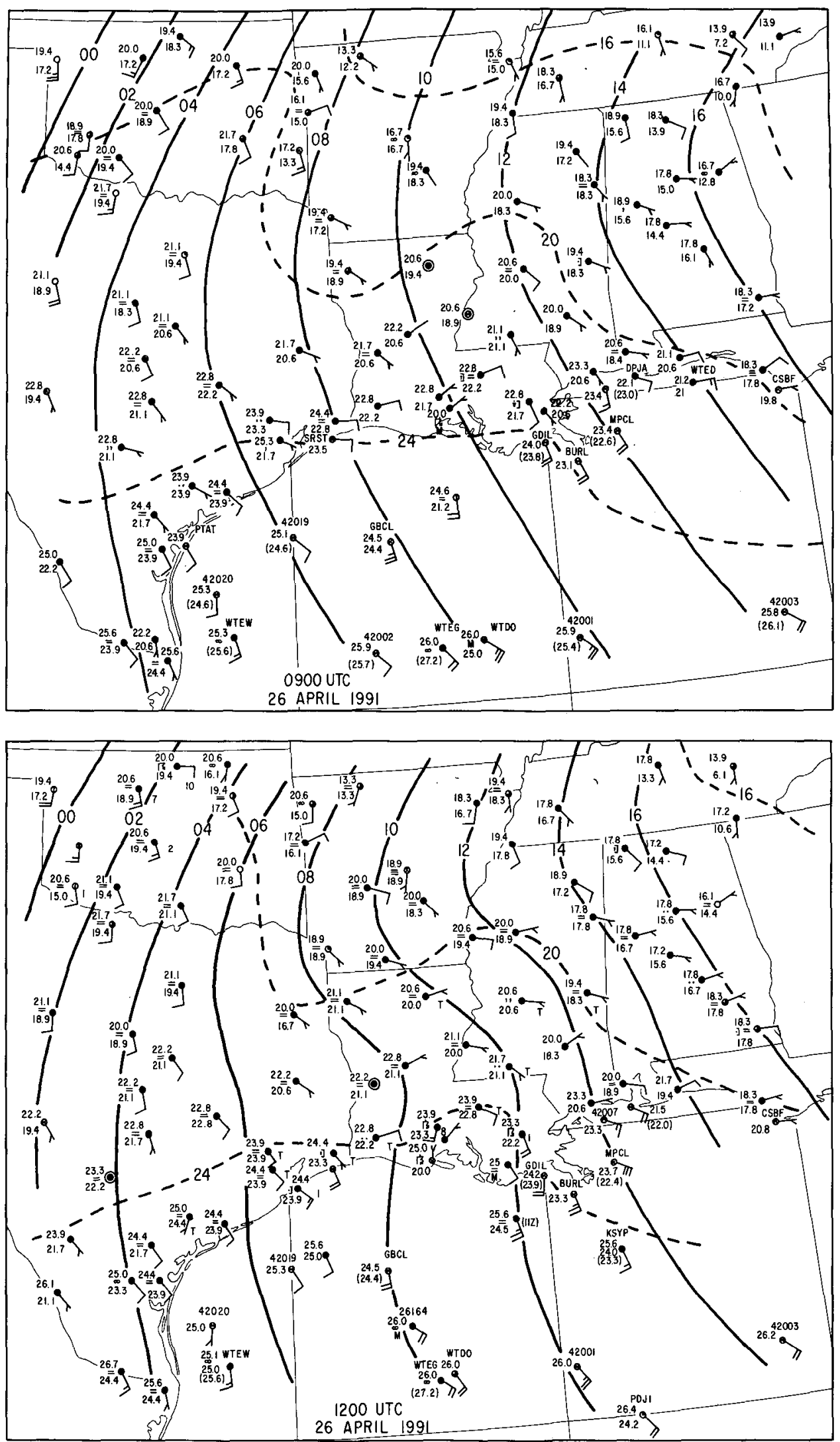

FIG. 2. Manual surface analyses for (a) 0900 UTC 26 April 1991 and (b) 1200 UTC 26 April 1991. Mean sea level isobars (solid) every $2 \mathrm{mb}$ and temperatures (dashed) every $4^{\circ} \mathrm{C}$. Winds with one pennant, full barb, and half-barb denote 25,5 , and $2.5 \mathrm{~m} \mathrm{~s}^{-1}$, respectively. Conventional plotting for temperature, dewpoint temperature, and present weather. 


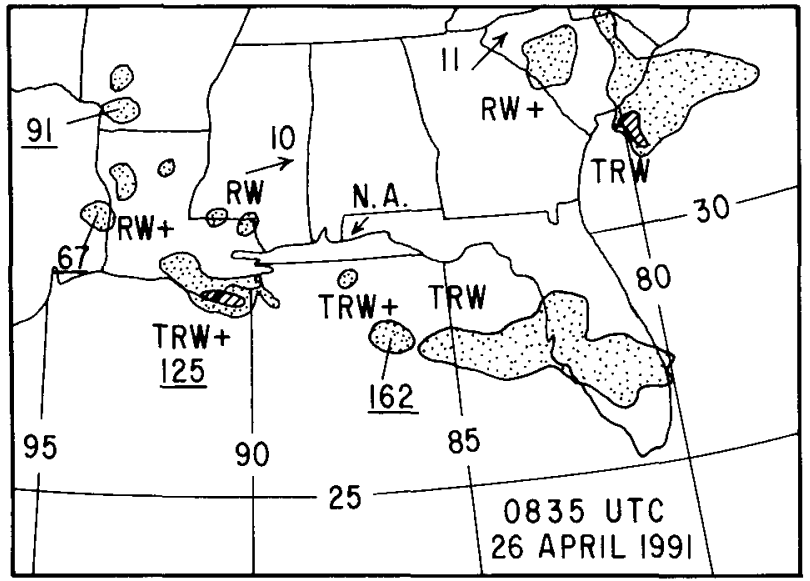

(a)

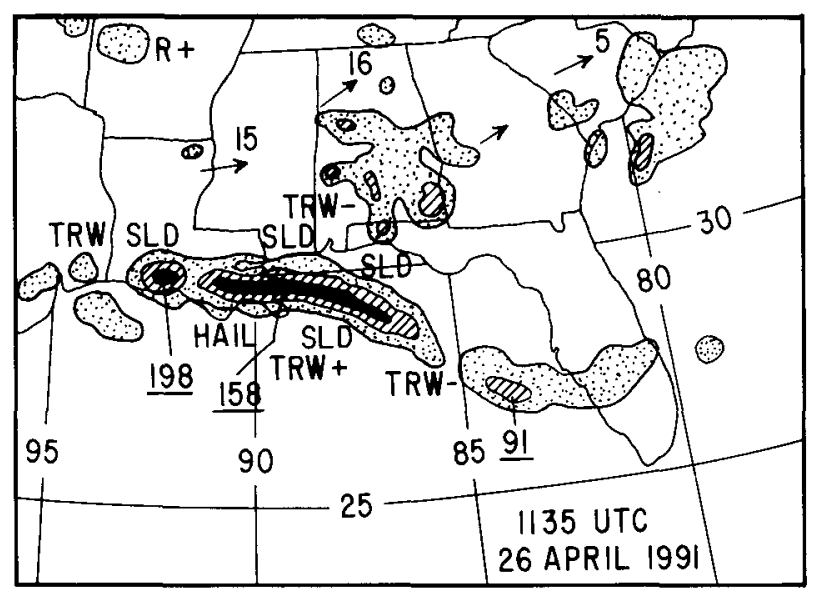

(b)

FIG. 3. National Weather Service manually digitized radar maps for (a) 0835 UTC 26 April 1991 and (b) 1135 UTC 27 April 1991. Conventional plotting with cloud-top heights in hundreds of meters and echo and cell movements in meters per second.

servations and conditions $12 \mathrm{~h}$ earlier. Slidell, Louisiana (SIL, 72233), may also be anomalously warm.

Differences with surrounding stations are more prominent at $150 \mathrm{mb}$ (Fig. 7). At this level, temperatures at both LCH and SIL are colder than surrounding stations by $4^{\circ}-6^{\circ} \mathrm{C}$. Furthermore, the 150 -mb wind at $\mathrm{LCH}$ is $15-20 \mathrm{~m} \mathrm{~s}^{-1}$ weaker than adjacent winds and is rotated approximately $50^{\circ}$ counterclockwise from the environmental wind direction.

The nature of these unusual local atmospheric conditions may be seen from the 1200 UTC soundings from LCH and SIL (Fig. 8). The LCH sounding (recall that operational National Weather Service practice precludes the routine transmission of moisture information at temperatures less than $-40^{\circ} \mathrm{C}$ ) reveals an atmosphere primed for the deep convection that was developing in the area at the time of the sounding ( sec- tion 2). The lifted index, $K$ index, and convective available potential energy are $-6^{\circ} \mathrm{C}, 28^{\circ} \mathrm{C}$, and 1701 $\mathrm{m}^{2} \mathrm{~s}^{-2}$, respectively. Veering and strengthening winds in the lower half of the troposphere suggest that warmair advection may have been an important lifting mechanism for destabilization. The feature of interest in the LCH sounding is the stable layer centered near $200 \mathrm{mb}$ that lies beneath a potentially warmer (by approximately $13^{\circ} \mathrm{C}$ ), nearly adiabatic layer that extends from $185 \mathrm{mb}$ to the reported tropopause at $135 \mathrm{mb}$. Note further how the ambient west-southwesterly flow of $30-40 \mathrm{~m} \mathrm{~s}^{-1}$ in the upper troposphere is replaced by a $15-20 \mathrm{~m} \mathrm{~s}^{-1}$ south-southwesterly flow within this nearly adiabatic layer. Furthermore, the wet-bulb potential temperature within the $185-135$-mb layer is very close to $24^{\circ} \mathrm{C}$, a value almost matched in the subcloud layer and corresponding to an equivalent potential temperature of $353 \mathrm{~K}$. This unusual near-adiabatic layer and the close agreement with the subcloud air lead us to hypothesize that the radiosonde balloon launched at LCH penetrated a cumulonimbus anvil and sampled air representative of the subcloud layer of the planetary boundary layer (PBL), which had been ejected from an undilute updraft core.

Conditions at SIL, approximately $300 \mathrm{~km}$ east of $\mathrm{LCH}$, differ in two important ways from $\mathrm{LCH}$. First, the winds in the upper half of the troposphere are a more uniform $35-40 \mathrm{~m} \mathrm{~s}^{-1}$ with little evidence of flow interruption. Second, the nearly adiabatic layer above $185 \mathrm{mb}$ that appeared to be representative of the subcloud layer of the PBL has been replaced by a weak stable layer between 280 and $250 \mathrm{mb}$ that underlies a potentially warmer layer extending upward to the tropopause near $140 \mathrm{mb}$. The SIL sounding suggests that the radiosonde balloon penetrated the base of a downwind anvil near $280 \mathrm{mb}$ in which partial mixing of cloud and environmental air has taken place.

For comparison purposes, the upper portion of the sounding for Jackson, Mississippi (JAN, 72235) is also replicated in Fig. 8. The JAN sounding is similar to other soundings outside the region of convection. The tropopause lies at $195 \mathrm{mb}$ with a temperature of $-59.5^{\circ} \mathrm{C}$. Comparison of the JAN, LCH, and SIL soundings clearly reveals the aforementioned $\mathrm{LCH}$ temperature anomaly above $200 \mathrm{mb}$.

A more detailed comparison between the 1200 UTC $\mathrm{LCH}$ sounding and environmental conditions in the upper troposphere and lower stratosphere is made in Fig. 9. Comparison of Figs. $6 \mathrm{a}$ and $6 \mathrm{~b}$ suggests that stations in the southern half of Texas at 0000 UTC 26 April should be representative of both preconvective conditions and the undisturbed environment over Louisiana and Mississippi at 1200 UTC. Accordingly, temperature soundings for the Texas stations of Midland (MAF, 72265), Longview (GGG, 72247), Corpus Christi (CRP, 72251), and Del Rio (DRT, 72261) are displayed in Fig. 9 along with the 0000 and 1200 UTC soundings from $\mathrm{LCH}$. 

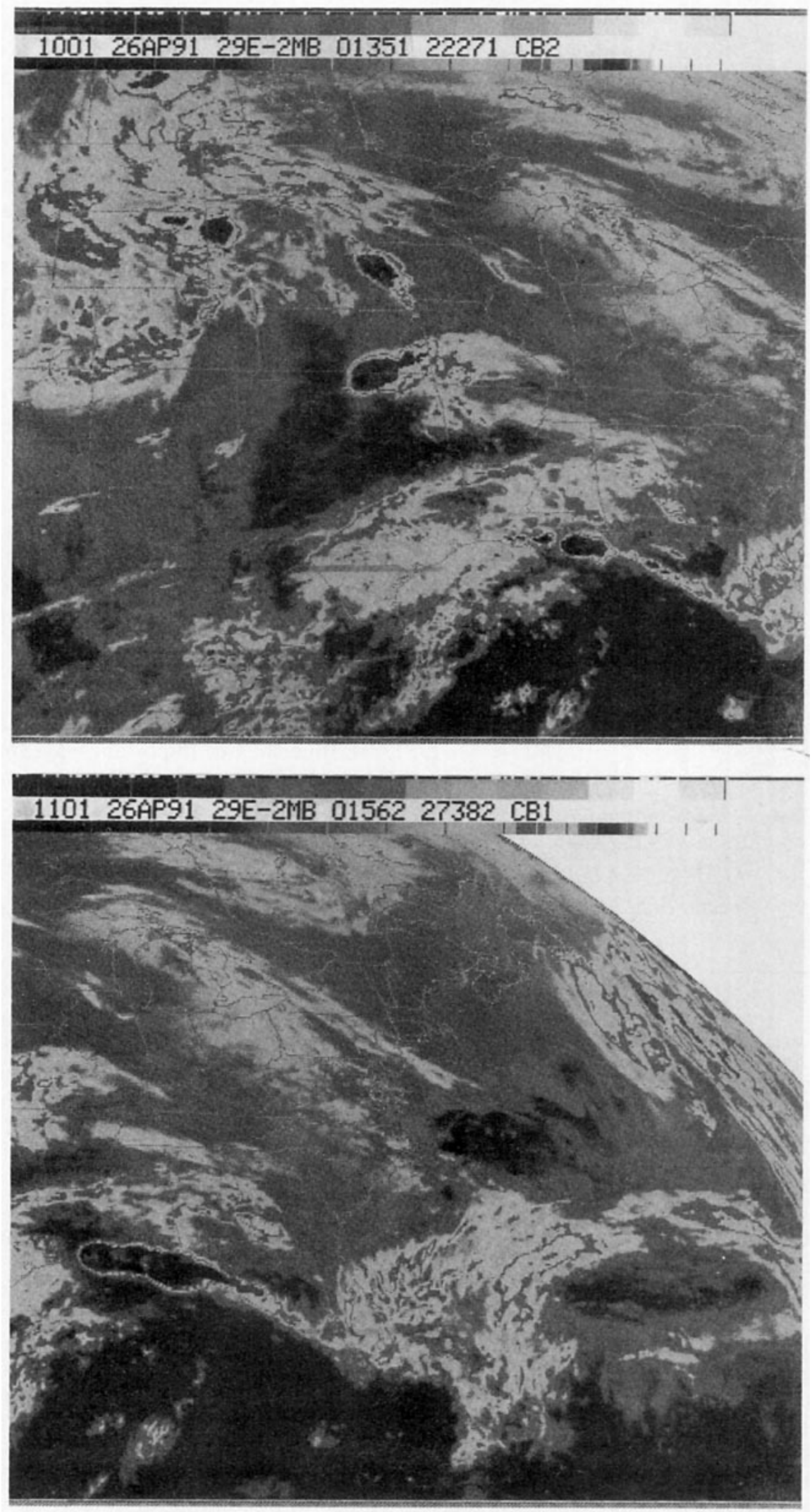

FIG. 4. Infrared satellite imagery [temperature scale for the operational MB curve is given at the top of the image with each tick mark representing a temperature change of $10^{\circ} \mathrm{C}$, colder to the right. The $0^{\circ} \mathrm{C}$ marker is found between the $\mathrm{MB}$ label and the leading zero in the five-digit number at the very top of the image. The complete temperature scale spans the range $50^{\circ} \mathrm{C}$ (left) to $-100^{\circ} \mathrm{C}$ (right)] for (a) 1001 UTC, (b) 1101 UTC, (c) 1201 UTC, and (d) 1401 UTC 26 April 1991. 

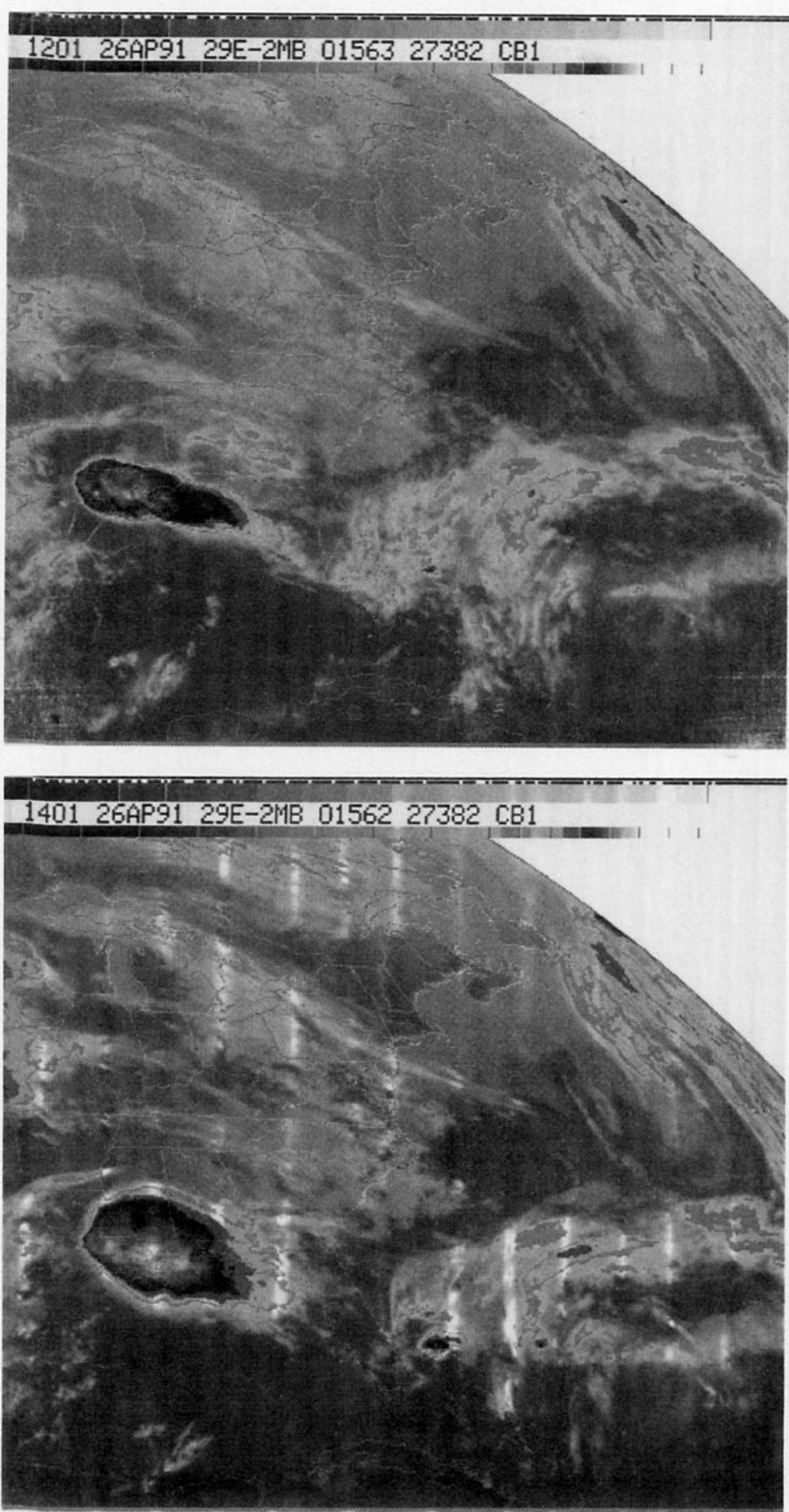

FIG. 4. (Continued) 

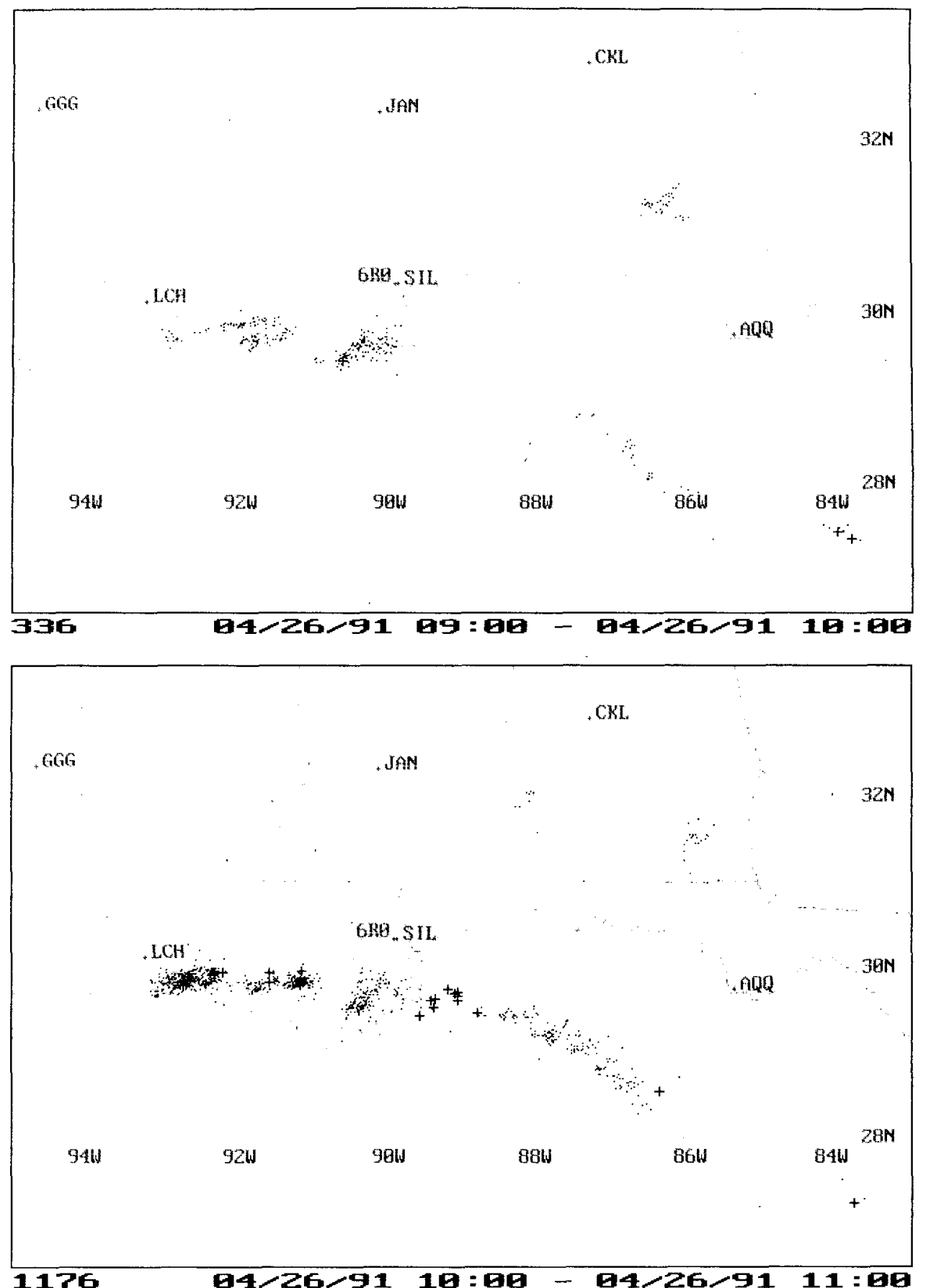

FIG. 5. Cloud-to-ground lightning location plots for (a) 0900-1000 UTC 26 April 1991, (b) 1000-1100 UTC 26 April 1991, (c) 1100-1200 UTC 26 April 199I, and (d) 1200-1300 UTC 26 April 1991. Plus (dot) symbols denote positive (negative) flashes. Selected stations shown according to the scheme given in Fig. 1.

The most prominent feature of Fig. 9 is the widespread similarity of the thermal structure in the 300 $100-\mathrm{mb}$ layer and the implied bland horizontal thermal gradients as seen, for example, in the pervasive 200 $\mathrm{mb}$ temperatures in the $-57^{\circ}$ to $-60^{\circ} \mathrm{C}$ range, as pre- viously mentioned in conjunction with Fig. 6 . The 0000 UTC soundings from MAF, CRP, GGG, DRT, and $\mathrm{LCH}$ all show a well-defined tropopause near $200 \mathrm{mb}$ with a temperature of $-60^{\circ} \mathrm{C}$ (potential temperature of $331 \mathrm{~K}$ ). Note also how the 1200 UTC sounding 

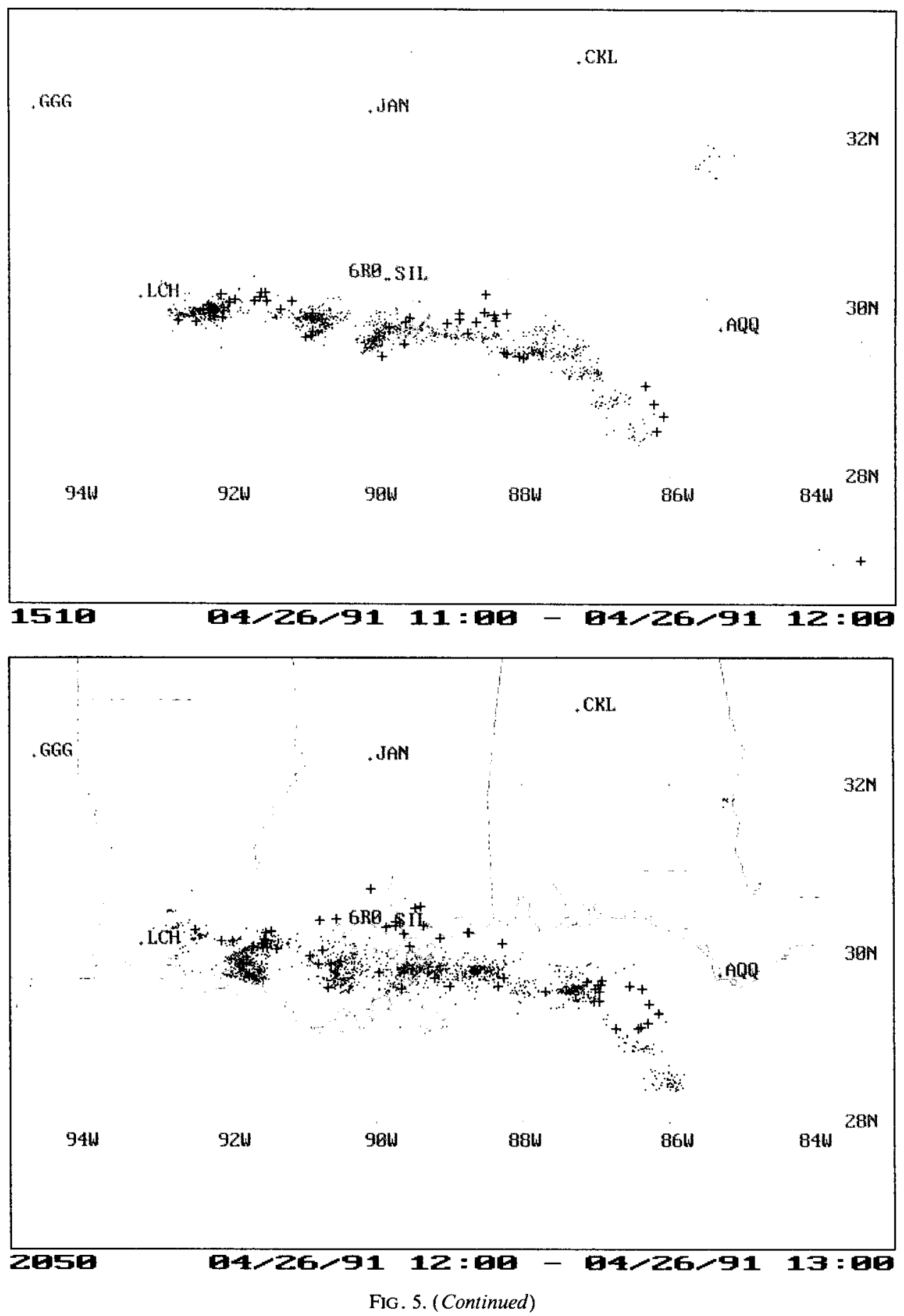

from JAN (Fig. 8), away from the area of rapidly developing convective anvils, is in good agreement with the upstream soundings displayed in Fig. 9.

Another prominent feature of Fig. 9 (also seen in Fig. 8 ) is the relatively cold lower stratosphere above $135 \mathrm{mb}$ at $\mathrm{LCH}\left(\sim-70^{\circ} \mathrm{C}\right)$. Given that our thunderstorm of interest lies along and somewhat to the south of the subtropical jet (STJ) axis (Fig. 7), the question arises as to whether there may have been a "tropopause break" in the vicinity of the STJ with higher and colder tropopauses to the south. This possibility was tested by examining the 1200 UTC 26 April soundings for Waycross, Georgia, the Florida stations of Apalachicola, Tampa, West Palm Beach, and Key 

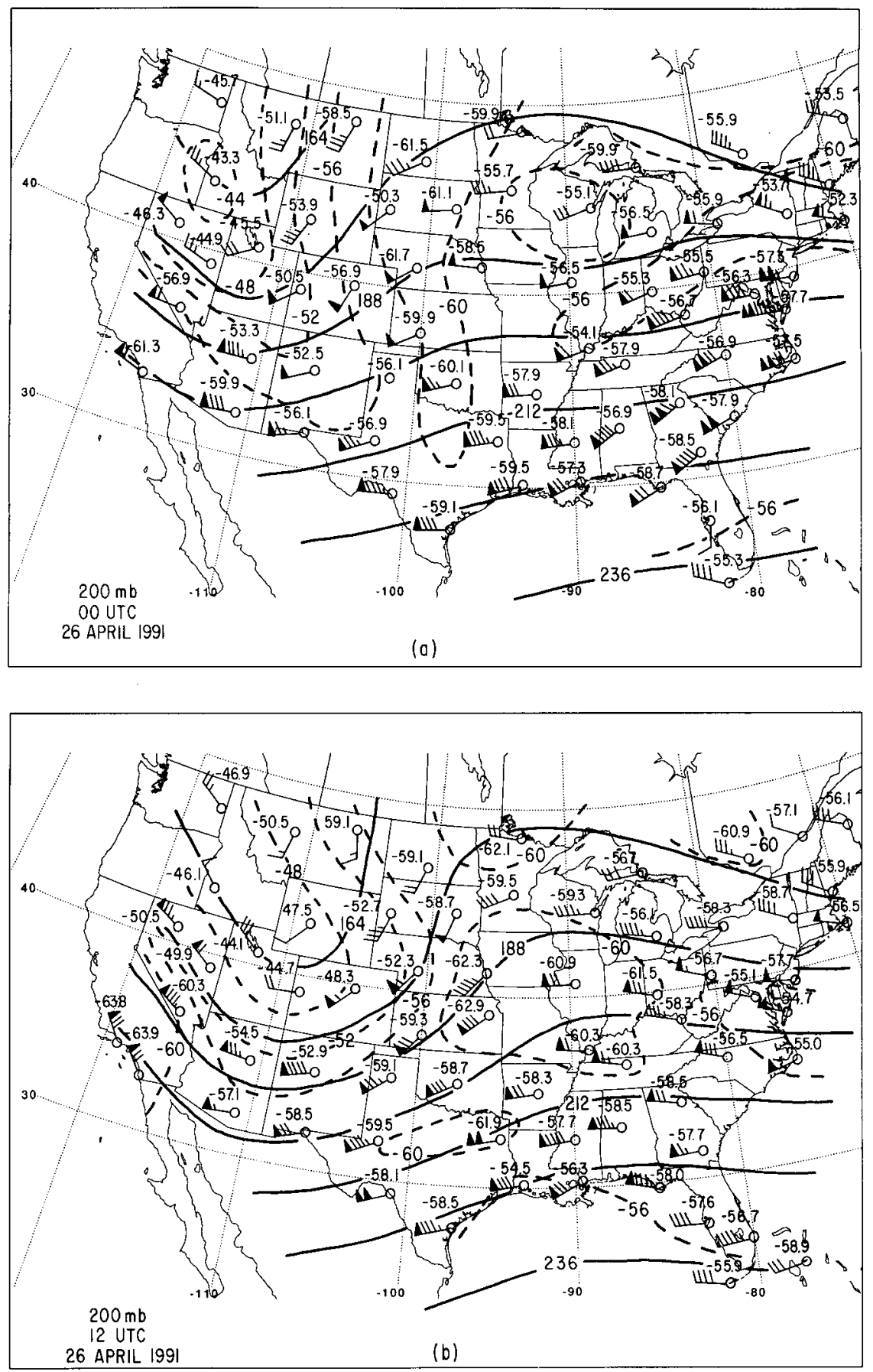

FIG. 6. Manual 200-mb analysis for (a) 0000 UTC 26 April 1991 and (b) 1200 UTC 26 April 1991. Geopotential heights (solid) every $12 \mathrm{dam}$ and temperatures (dashed) every $4^{\circ} \mathrm{C}$. Winds as in Fig. 2. Plotted numbers to the left of the stations are the reported temperatures in tenths of a degree Celsius.

West, and Nassau in the Bahamas. The reported and estimated mean temperature in the lower stratosphere (tropopause to $100 \mathrm{mb}$ ) for these six stations is: $168 \mathrm{mb}\left(\sim-63^{\circ} \mathrm{C}\right), 170 \mathrm{mb}\left(\sim-66^{\circ} \mathrm{C}\right)$, $172 \mathrm{mb}\left(\sim-64^{\circ} \mathrm{C}\right), 153 \mathrm{mb}\left(\sim-64^{\circ} \mathrm{C}\right), 146 \mathrm{mb}$ $\left(\sim-65^{\circ} \mathrm{C}\right)$, and $170 \mathrm{mb}\left(\sim-64^{\circ} \mathrm{C}\right)$, respectively. These values suggest that the tropopause gradually ascends southward across Florida to the south of the STJ axis, but even in southern Florida the lower stratosphere is approximately $5^{\circ} \mathrm{C}$ warmer than at $\mathrm{LCH}$. 


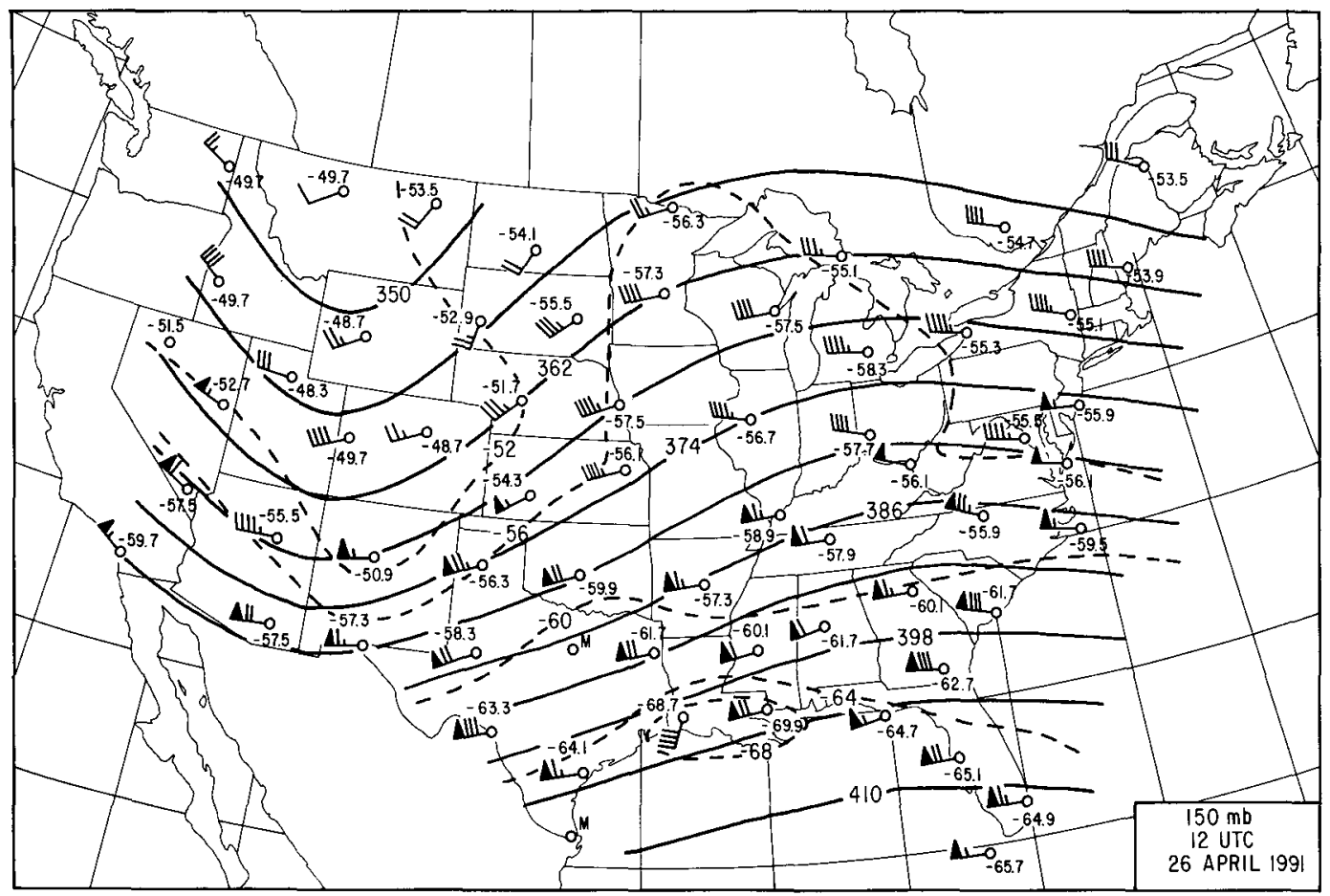

Fig. 7. As in Fig. 6 except for $150 \mathrm{mb}$ at 1200 UTC 261991.

These findings reinforce our assertion that the tropopause has been lifted locally in the vicinity of the rapidly spreading anvil at 1200 UTC 26 April.

It is obvious by comparing the 1200 UTC LCH sounding with the other soundings shown in Fig. 9 that the $\mathrm{LCH}$ thermal anomaly above $250 \mathrm{mb}$ could not have arisen by ordinary adiabatic lifting, horizontal advection, or radiative cooling above cloud tops. An additional possibility, that shear instability produced the mixed layer in the lower stratosphere, is removed by the extreme amount of mixing that would have taken place, the lack of low Richardson numbers indicative of shearing instability in the upstream soundings, the near uniformity of the upstream environment, and the lack of unusually strong vertical shear in the 1200 UTC LCH sounding between points below and above the mixed layer.

According to Fig. 8 the radiosonde balloon launched from LCH penetrates the undilute anvil near $200 \mathrm{mb}$ at an altitude of approximately $12 \mathrm{~km}$. The typical 0.6 $\mathrm{kg}$ NWS radiosonde balloon ascends at a rate of 5 $\mathrm{m} \mathrm{s}^{-1}$, which implies an interval of about $40 \mathrm{~min}$ between launch and anvil penetration. Given that the time of nominal balloon launch is approximately 1115 UTC under standard NWS procedures, the balloon would have reached the $200-\mathrm{mb}$ level at 1155 UTC. The mean vector wind between the ground and 200 $\mathrm{mb}$ is estimated from the sounding as $25 \mathrm{~m} \mathrm{~s}^{-1}$ from $241^{\circ}$, which places the balloon approximately $60 \mathrm{~km}$ downwind of LCH at 1155 UTC.
Comparison with the 1201 UTC infrared satellite image shown in Fig. $4 \mathrm{c}$ reveals the existence of a welldefined western edge to the rapidly growing anvil along the Louisiana coast. This convective cloud edge is estimated to lie $60-70 \mathrm{~km}$ to the east of $\mathrm{LCH}$. Furthermore, the minimum observed rawinsonde temperature at the top of the anomalous layer, $-74^{\circ} \mathrm{C}$, is only a few degrees colder than the infrared brightness temperatures near the western end of the anvil at 1201 UTC. We conclude that the radiosonde balloon launched from LCH at approximately 1115 UTC 26 April penetrated an undilute or nearly undilute cumulonimbus anvil on the western edge of a rapidly growing convective cluster located over extreme southcentral Louisiana near the 200 -mb level shortly before 1200 UTC. It appears that the LCH sounding has been produced by the injection of a large amount of mixed boundary-layer air into the lower stratosphere, with resulting upward and downward displacements of ambient air above and below the mixed layer. Although the reported tropopause is higher at $\mathrm{LCH}$ than at surrounding stations, the original tropopause near $195 \mathrm{mb}$ has been displaced downward to $215 \mathrm{mb}$ by the intrusion of the anvil above $200 \mathrm{mb}$.

\section{Kinematics of the thunderstorm anvil}

The magnitude of the wind perturbation within the mixed layer is extreme. The maximum vector wind difference, found between $200 \mathrm{mb}$ (beneath the anvil) 


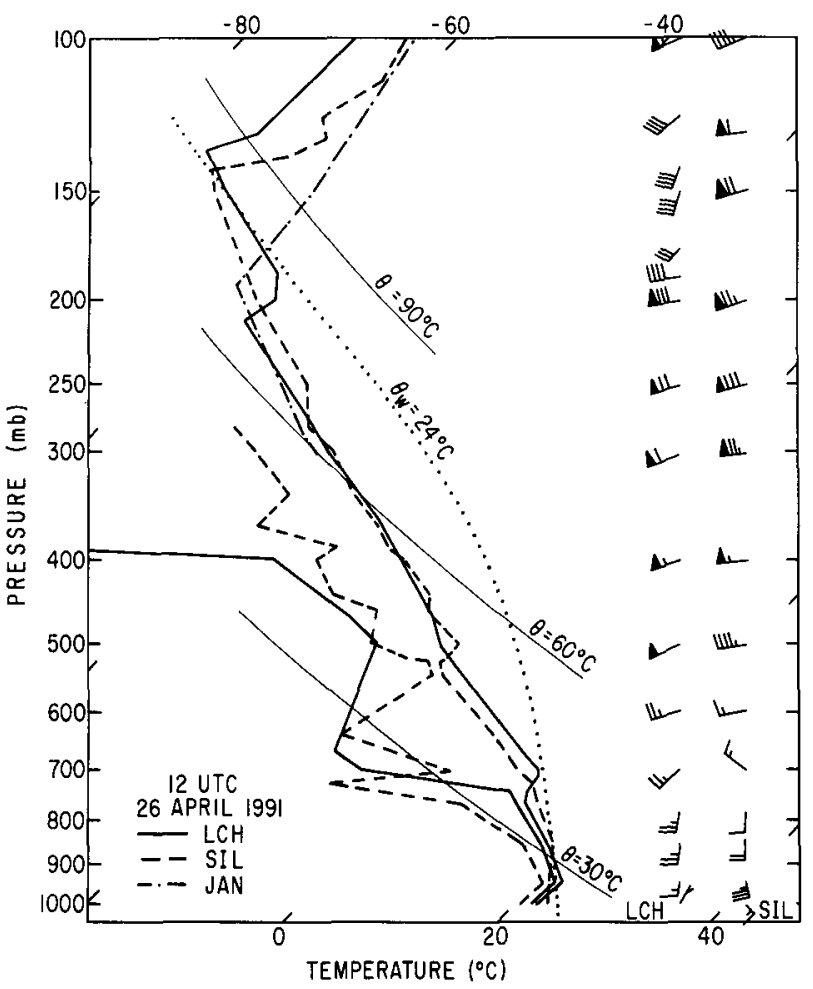

FIG. 8. Soundings (skew $T-\log p$ format) at 1200 UTC 26 April 1991 for Lake Charles, Louisiana (LCH, solid lines), and Slidell, Louisiana (SIL, dashed lines). The $300-100-\mathrm{mb}$ temperature portion of the Jackson, Mississippi (JAN) sounding is shown as a dash-dot line. The $24^{\circ} \mathrm{C}$ wet-bulb potential temperature curve is drawn as a dotted line.

and $150 \mathrm{mb}$ (within the anvil), is $35 \mathrm{~m} \mathrm{~s}^{-1}$ from $110^{\circ}$. [A wind perturbation of this magnitude is also consistent with that estimated by Newton (1966) and Bluestein et al. (1988) for an extreme updraft of $50 \mathrm{~m} \mathrm{~s}^{-1}$ in an active undilute convective tower.] Taking for the environmental wind the winds observed at surrounding stations at $150 \mathrm{mb}$, the environmental vector wind difference is $29 \mathrm{~m} \mathrm{~s}^{-1}$ from $110^{\circ}$. Although the observed winds within the anvil are more similar to surface boundary-layer winds along the coast than to the ambient 200 - or 150 -mb flow, it is unlikely that air parcels experienced no horizontal accelerations during their ascent through the cumulonimbi. It is more plausible that the wind perturbation may be representative of the strength of the divergent outflow from the thunderstorm turrets. The perturbation wind direction, $110^{\circ}$, is consistent with the balloon having penetrated the western edge of the anvil, even if a slight Coriolis turning of the wind is allowed for. To consider whether the hypothesis of $29 \mathrm{~m} \mathrm{~s}^{-1}$ divergent flow is reasonable, we compare the observed winds with outflow velocities estimated from satellite imagery and from a simple model of an internal density current.

The satellite imagery, particularly Figs. $4 \mathrm{~b}$ and $4 \mathrm{c}$, indicates that the thunderstorms formed along a line across southern Louisiana. The overshooting tops, whose locations are assumed to correspond to the sources of anvil outflow, are oriented almost west-east from south-central Louisiana to south of the coast of Mississippi. This configuration permits the estimation of the strength of the anvil outflow from the rate of separation of the northern and southern edges of the cirrus shield. According to Figs. $4 \mathrm{~b}$ and $4 \mathrm{c}$, the northern and southern edges move apart by between 120 and $150 \mathrm{~km}$ in $1 \mathrm{~h}$. Assuming the centroid of the anvil is drifting with the mean wind, the perturbation wind speed at either the northern or southern edge of the anvil would be about $18 \mathrm{~m} \mathrm{~s}^{-1}$. Similar speeds are obtained from a comparison of Figs. $4 \mathrm{c}$ and $4 \mathrm{~d}$. These estimated speeds are smaller by $11-17 \mathrm{~m} \mathrm{~s}^{-1}$ than the observed rawinsonde winds, suggesting that the instantaneous rawinsonde observation may have been affected by turbulence within the anvil, short-term variations in outflow velocity, or an asymmetrical outflow.

Thunderstorm anvils have been described as examples of internal density (gravity) currents (Simpson 1987). An internal density current consists of an intrusion of homogeneous fluid within a stratified environment, with the upper portion of the fluid denser than its environment and the lower portion less dense that its environment. Either half of the intrusion may be treated as though it is propagating along a horizontal boundary. Here, we can consider the lower portion of the anvil, which is warmer than its environment. The ambient stability in the neighborhood of the anvil is complex, so an estimate of the expected density current speed made from the LCH sounding can only be ex-

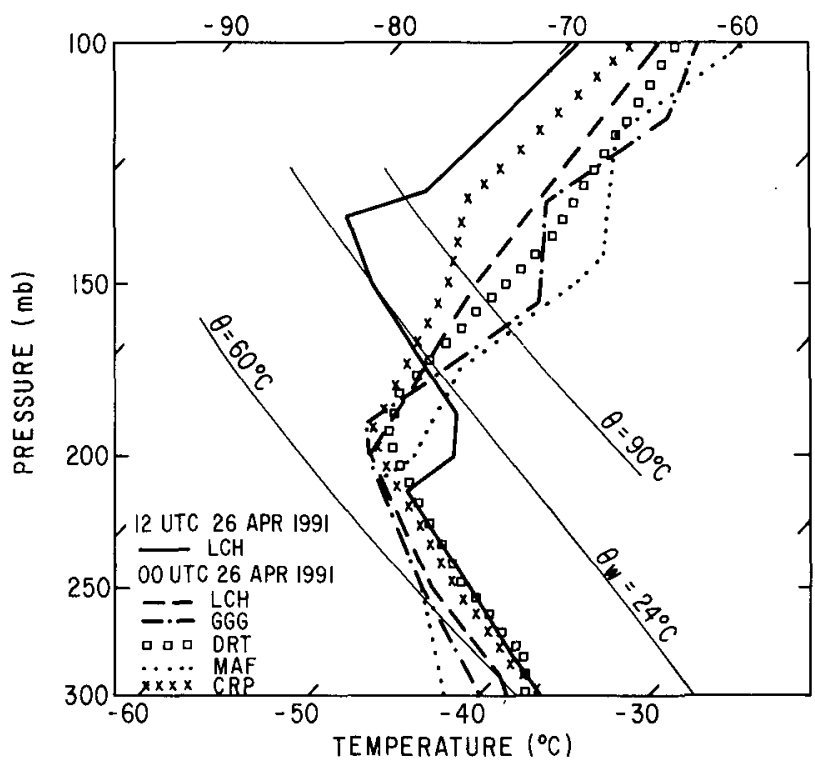

FlG. 9. As in Fig. 8 except for 0000 UTC 26 April 1991 for Lake Charles, Louisiana (LCH), Del Rio, Texas (DRT), Corpus Christi, Texas (CRP), Midland, Texas (MAF), and Longview, Texas (GGG). The upper-tropospheric portion of the 1200 UTC 26 April $1991 \mathrm{LCH}$ sounding (Fig. 8) is shown for comparison. 
pected to be within a factor of 2 of the actual velocity of a buoyancy-driven outflow. Taking the environment to be defined by the 0000 UTC 26 April CRP and DRT soundings (Fig. 9), the zero-buoyancy level of the internal density current is estimated to be $170 \mathrm{mb}$ $(12.8 \mathrm{~km})$. Below this level, the density current has an estimated densimetric depth of $30 \mathrm{mb}(1.0 \mathrm{~km})$. The estimated potential temperature perturbation $\theta^{\prime}$ of the outflow is $13^{\circ} \mathrm{C}$, so, assuming a Froude number of unity and a mean potential temperature $\theta$ of approximately $340 \mathrm{~K}$, the velocity of the anvil relative to the environment $C$ would be

$$
C=\left(\frac{g H \theta^{\prime}}{\theta}\right)^{1 / 2}=19.4 \mathrm{~m} \mathrm{~s}^{-1},
$$

which is consistent with the observed spreading of the anvil.

\section{Downstream conditions at 0000 UTC 27 April 1992}

By this time the convection over the southeastern United States had begun to weaken. Figure 10 shows an infrared satellite image for 1901 UTC 26 April. Comparison with the earlier pictures displayed in Fig. 4 reveals that the convective cloud-top debris had expanded over a wide domain in a quasi-circular fashion, analogous to what is frequently seen in a warm-season mesoscale convective complex (MCC). Still later at 2330 UTC (not shown) the coldest cloud tops had started to break up as the convection weakened. However, anvil debris evident over most of Georgia and portions of northern Florida and extreme southwestern South Carolina at 1901 UTC still covered much of the region. Accordingly, the 0000 UTC NWS sounding releases (approximate launch time of about 2315 UTC) from Waycross, Georgia (AYS, 72213), Athens, Georgia (AHN, 72311), and Charleston, South Carolina (CHS, 72208), probably sampled this anvil debris. Likewise, the 200-mb map analysis for 0000 UTC 27 April (not shown) shows a similar broad west-southwesterly flow of $35-40 \mathrm{~m} \mathrm{~s}^{-1}$ from Louisiana to the Carolinas, consistent with what we saw at 0000 and 1200 UTC 26 April in Fig. 6. Temperatures at $200 \mathrm{mb}$ over this region once again are in the $-57^{\circ}$ to $-60^{\circ} \mathrm{C}$ range and there is no evidence for any wind or temperature perturbations at this level. This statement is tempered by the knowledge that radiosonde data from the NWS site at Apalachicola, Florida (AQQ, 72220), was not available for analysis.

Representative 0000 UTC 27 April soundings for AYS and AHN are shown in Figs. 1 la,b. Both of these soundings (as well as the CHS sounding, not shown) show residual effects of the anvil debris above the 200 -

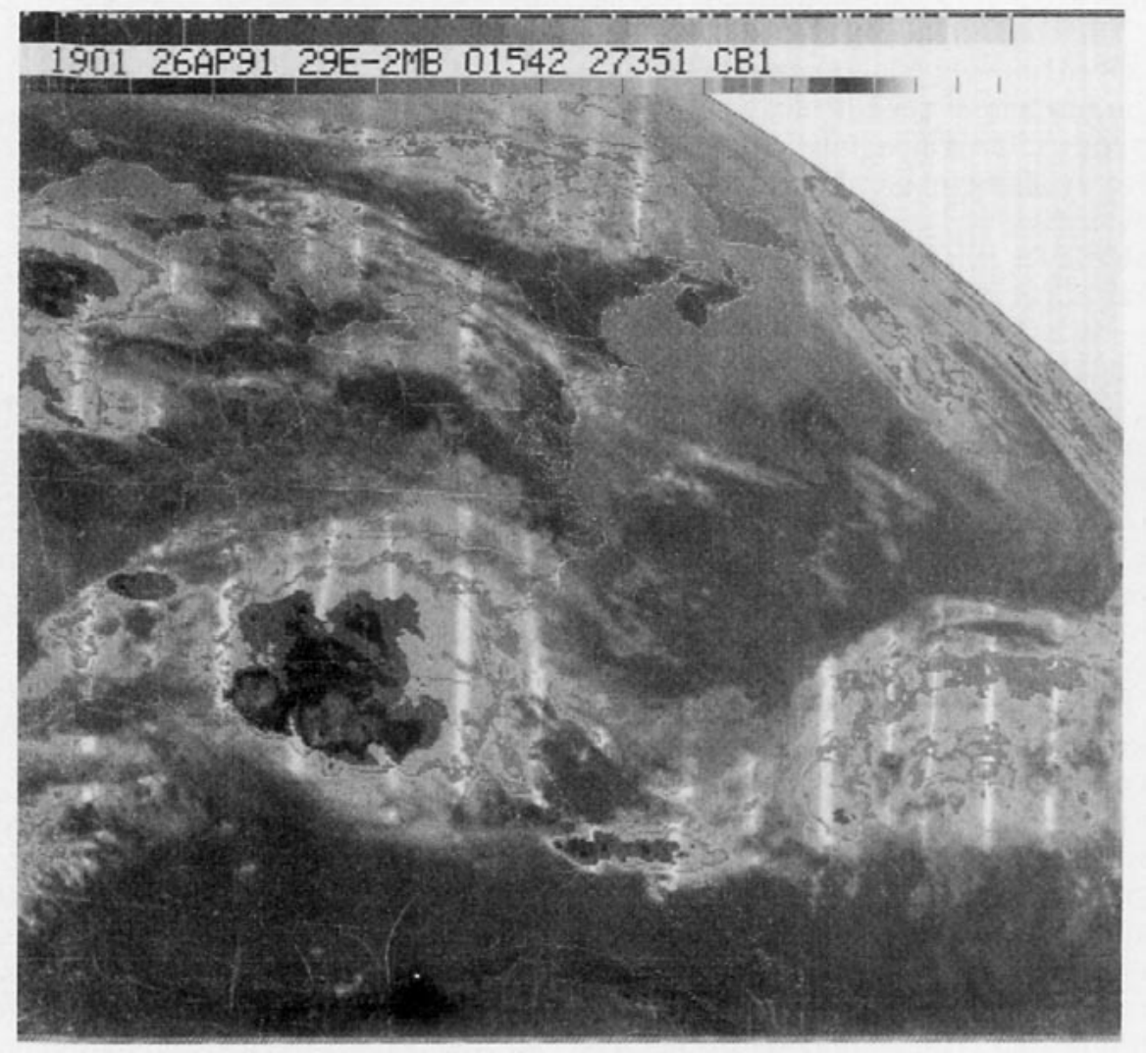

FIG. 10. As in Fig. 4 except for 1901 UTC 26 April 1991. 
mb level as judged by the change in stability near 200 $\mathrm{mb}$ (remnant of the undisturbed upstream environmental tropopause $12 \mathrm{~h}$ earlier) and the $-66^{\circ}$ to $-68^{\circ} \mathrm{C}$ cold pocket between 170 and $160 \mathrm{mb}$. Comparison with the LCH 1200 UTC sounding shown in Fig. 8 suggests that the AYS and AHN temperature profiles can evolve from the LCH profile, given ascent at the base of the stable layer near $200 \mathrm{mb}$ and subsidence, possibly associated with collapsing updraft cores and/ or lateral mixing, in the vicinity of the $-74^{\circ} \mathrm{C}$ cold dome near $135 \mathrm{mb}$. The modest increase in stability near $200 \mathrm{mb}$ at AYS and AHN (also at CHS, not shown) hints at the possibility of a tropopause attempting to form at the level of the original upstream tropopause. These comparisons suggest a slow readjustment to ambient environmental conditions in the upper troposphere and lower stratosphere in which horizontal and lateral mixing processes (just above the anvil) as well as radiative processes are playing an important but undefined role.

\section{Summary and concluding remarks}

This paper has presented evidence for the lifting of a layer of subcloud air to above the tropopause in a nearly undilute deep convective updraft core through the serendipitous penetration of the storm anvil near $200 \mathrm{mb}$ by the NWS radiosonde balloon launched operationally from Lake Charles, Louisiana at 1115 UTC 26 April 1991. The convective cloud was penetrated by the balloon approximately $60-70 \mathrm{~km}$ to the east of LCH. The sounding itself reveals an atmosphere primed for deep convection with a lifted index of $-6^{\circ} \mathrm{C}$ and a convective available potential energy of 1701 $\mathrm{m}^{2} \mathrm{~s}^{-2}$. The noteworthy aspect of the $\mathrm{LCH}$ sounding is the $25-\mathrm{mb}$ stable layer centered around $200 \mathrm{mb}$ (potential temperature increase of approximately $13^{\circ} \mathrm{C}$ ) that underlies a nearly adiabatic layer from 185 to 135 $\mathrm{mb}$ where the temperature is $-74^{\circ} \mathrm{C}$, considerably colder than the ambient tropopause temperatures of $-60^{\circ} \mathrm{C}$ found in the nearby undisturbed environment as well as upstream $12 \mathrm{~h}$ earlier. The thermal structure above $200 \mathrm{mb}$ at LCH cannot be obtained by adiabatically lifting the existing air mass from the ambient preconvective tropopause.

The wet-bulb potential temperature of the subcloud layer of $24^{\circ} \mathrm{C}$ lies within $1{ }^{\circ} \mathrm{C}$ of the wet-bulb potential temperature of the 185-135-mb layer (approximately $2.3 \mathrm{~km}$ in thickness) that contains the lifted air. The potential temperature in this anomalously warm layer is $13^{\circ} \mathrm{C}$ higher than would be found in undisturbed nearby and upstream locations by extrapolating the reported tropopause of $-60^{\circ} \mathrm{C}$ near $200 \mathrm{mb}$ upward adiabatically. Similarly, the winds average $15-20 \mathrm{~m} \mathrm{~s}^{-1}$ from the south-southwest over the $185-135$-mb layer and are more representative of the $10-15 \mathrm{~m} \mathrm{~s}^{-1}$ southerly flow in the subcloud layer as opposed to the undisturbed west-southwesterly winds of $35-40 \mathrm{~m} \mathrm{~s}^{-1}$
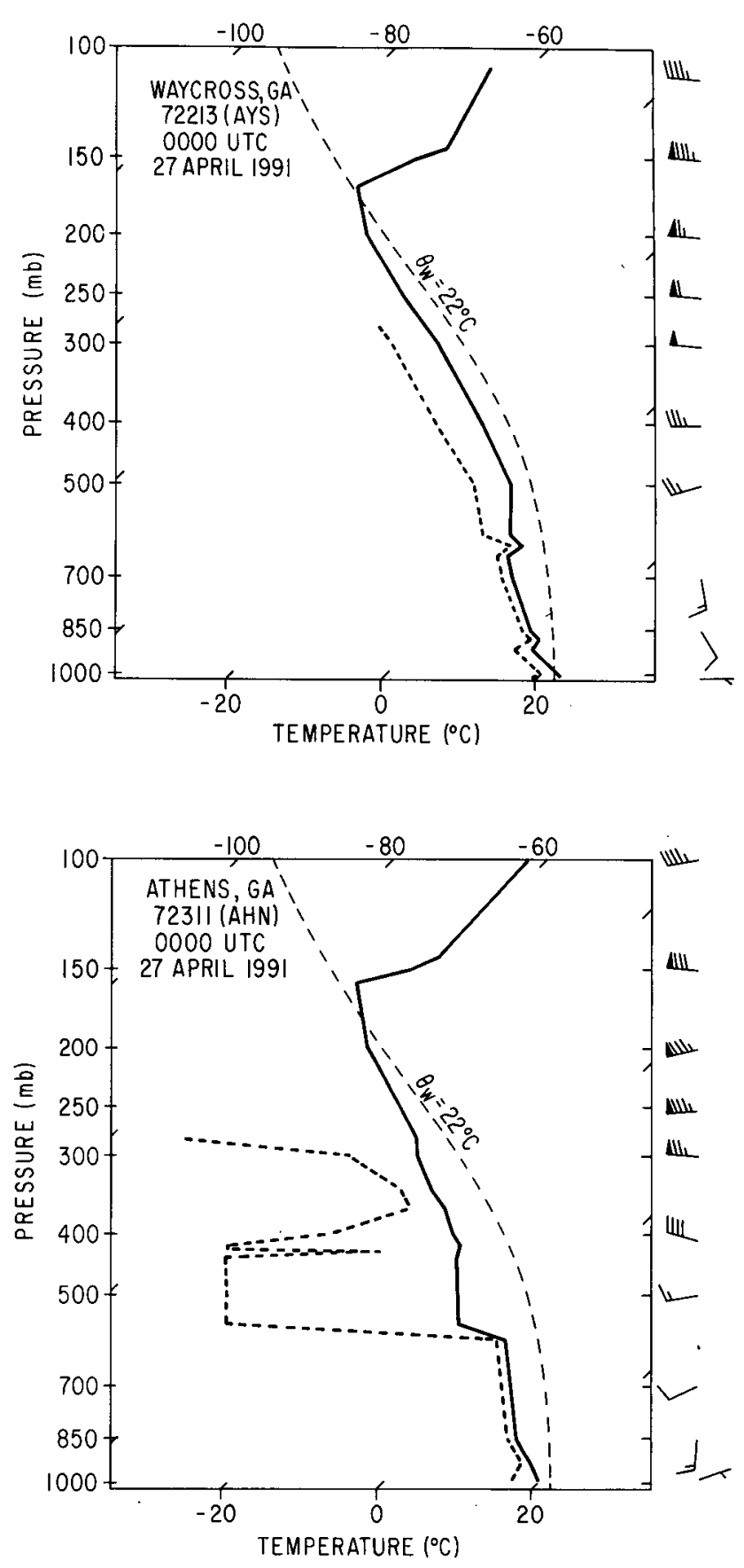

FIG. 11. As in Fig. 8 except for 0000 UTC 27 April 1991 at (a) Waycross, Georgia (AYS), and (b) Athens, Georgia (AHN).

near the tropopause. The nearly steady-state large-scale flow pattern in the upper troposphere with a quasiuniform tropopause near $200 \mathrm{mb}$ and a temperature of $-60^{\circ} \mathrm{C}$ at both 0000 and 1200 UTC away from the convectively active region enabled us to rule out any important role for horizontal advection in producing the well-defined thermal anomaly and mixed layer. The possibility that shear instability produced the mixed 
layer in the lower stratosphere was discounted on the basis of the absence of low Richardson numbers in a quasi-uniform upstream environment and the lack of appreciable vertical wind shear across the mixed layer.

The implications of this sounding extend beyond mere novelty. An important climate issue is the role that water vapor in the upper troposphere and lower stratosphere plays in the heat and moisture budget of the atmosphere and the question of stratospheric and tropospheric exchange. Danielsen (1982a,b) argued that the observed dehydration of the lower stratosphere (water vapor mixing ratios are at a minimum $2-3 \mathrm{~km}$ above the tropical tropopause) can occur, in part, through the radiative destabilization of thick cirrus anvils in the aftermath of deep convection. This led Danielsen (1982b) and Doherty et al. (1984) to argue that rapidly expanding cirrus outflows at the tropopause level above and downshear of organized deep convection in the tropics could be an important component of stratospheric-tropospheric exchange processes, a viewpoint supported theoretically by Lilly (1988) in a study of cirrus outflow dynamics and numerically by Ackerman et al. (1988) in an investigation of heating rates in tropical anvils.

The $\mathrm{LCH}$ sounding presents direct evidence for the nearly undilute ascent of subcloud air to a level higher (by $2.6 \mathrm{~km}$ ) and colder (by $13^{\circ} \mathrm{C}$ ) than the surrounding undisturbed tropopause. Downstream soundings through the anvils of the decaying convection $12 \mathrm{~h}$ later still showed some evidence of the thermal anomaly induced by the deep convection in the form of a cold anomaly in the 170-160-mb layer, matching the level of the reported minimum temperature found at 165 $\mathrm{mb}$ at LCH at 1200 UTC 26 April. However, temperatures in the downstream anomaly had warmed up by $6^{\circ}-8^{\circ} \mathrm{C}$ as the ambient tropopause attempted to reform. We are unable to say what role horizontal and vertical mixing processes as well as radiative processes played in the slow modification of the tropopause thermal structure after the initial penetration by the active updraft cores.

Soundings that depict apparently undilute tropospheric air injected into the lower stratosphere are rare. Special circumstances associated with the present case include a very deep initial layer of moist air near the surface and the unusually rapid development of a cirrus shield. It is also plausible that only certain portions of a thunderstorm anvil will be composed of undilute boundary-layer air. The satellite imagery suggested that the radiosonde penetrated the upstream edge of the anvil. If the spreading of the outflow is governed by buoyancy effects, dilute air, being closer in potential temperature to the upper-troposphere environment, will spread less quickly than the undilute air from the core of the updraft. In addition, upstream of the thunderstorms, only the air which is most buoyant relative to the upper troposphere will be able to make headway against the ambient upper-level flow. Therefore, we hypothesize that this unusual sounding is a consequence of the radiosonde balloon having penetrated the edge of the anvil upstream of the vigorously developing convection.

We conclude with some comments about the analysis of moisture in the atmosphere. As noted by Schwartz and Doswell (1991) current operational practice by the NWS in the United States is to cut off the routine transmission of moisture information when the relative humidity falls below $20 \%$ in which case a dewpoint depression of $30^{\circ} \mathrm{C}$ is automatically assigned to any temperature reading under these conditions. Wade (1991), however, indicates that the current hygristor flown operationally on the sondes in use today does retain accuracy at low relative humidities and that this information could be supplied without having to resort to an arbitrary cutoff if the transfer equation relating resistance to percent relative humidity is recalibrated properly. Given that Canadian stations routinely report relative humidities below $20 \%$ (as do United States military radiosondes) and that dewpoint depressions greater than $30^{\circ} \mathrm{C}$ were routinely reported in the United States up into the early 1970s, it would seem that the time is ripe to reconsider whether routine operational bureaucratic procedures are stifling the transmission of scientifically important moisture data. A companion issue, related to the current problem, is how to obtain useful quantitative moisture observations at cold temperatures in the upper troposphere and lower stratosphere. Current NWS operational practice in the United States is to cease the transmission of moisture data at temperatures less than $-40^{\circ} \mathrm{C}$. Perhaps this practice can also be reexamined in light of the growing scientific interest in the global distribution of water vapor and its importance to climate-related issues, a situation anticipated by Lorenz (1970). Because of these and other limitations we are unable to make any definitive statements about the direct or indirect deposition of water vapor into the lower stratosphere that occurred as the result of undilute parcel ascent and/or lateral and vertical mixing processes and/or cloud radiative processes that occurred in the deep convective cores of the mesoscale convective system just described.

Acknowledgments. The authors appreciate the help of Winston Hao, Michael Morgan, and Anton Seimon in providing data and computer assistance. Barry Schwartz provided helpful discussions about radiosonde characteristics. The comments of the anonymous referees and Chester Newton resulted in an improved text. We thank David Peters of CONOCO for providing information on marine observations in the Gulf of Mexico. The manuscript was prepared by Celeste Iovinella and the figures were drafted by Marilyn Peacock. Research support was provided by National Science Foundation Grants ATM-9114598, and ATM8805550 . 


\section{REFERENCES}

Ackerman, T. P., and K.-N. Liou, F. P. J. Valero, and L. Pfister, 1988: Heating rates in tropical anvils, J. Atmos. Sci., 45, 16061623.

Austin, J. M., and A. Fleischer, 1948: A thermodynamic analysis of cumulus convection. J. Meteor., 5, 240-243.

Bluestein, H. B., E. W. McCaul Jr., G. P. Byrd, and G. R. Woodall, 1988: Mobile sounding observations of a tornadic storm near the dryline: The Canadian, Texas storm of 7 May 1986. Mon. Wea. Rev., 116, 1790-1804.

Danielsen, E. F., 1982a: Statistics of cold cumulonimbus anvils based on enhanced infrared photographs. Geophys. Res. Lett., 9, 601604.

- 1982b: A dehydration mechanism for the stratosphere. Geophys. Res. Lett., 9, 605-608.

Davies-Jones, R. P., 1974: Discussion of measurements inside highspeed thunderstorm updrafts. J. Appl. Meteor., 13, 710-717.

Doherty, G. M., R. E. Newell, and E. F. Danielsen, 1984: Radiative heating rates near the stratospheric fountain. J. Geophys. Res., 89, 1380-1384.

Lilly, D. K., 1988: Cirrus outflow dynamics. J. Atmos. Sci., 45, 15941605.

Lorenz, E., 1970: The nature of the global circulation of the atmosphere: A present view. The Global Circulation of the Atmosphere, G. A. Corby, Ed., Royal Meteor. Soc., 3-23.

Newton, C. W., 1966: Circulations in large sheared cumulonimbus. Tellus, 18, 699-712.

Orville, R. E., 1991: Lightning ground flash density in the contiguous United States-1989. Mon. Wea. Rev., 119, 573-577.

$\longrightarrow$, R. W. Henderson, and L. F. Bosart, 1983: An East Coast light- ning detection network. Bull. Amer. Meteor. Soc., 64, 10291037.

Riehl, H., 1979: Climate and Weather in the Tropics. Academic Press, $611 \mathrm{pp}$.

- and J. S. Malkus, 1957: On the heat balance and maintenance of circulation in the trades. Quart. J. Roy. Meteor. Soc., 83, $21-$ 29.

,--1958 : On the heat balance of the equatorial trough zone. Geophysica, 6, 503-538.

- and J. Simpson, 1979: The heat balance of the equatorial trough zone, revisited. Beitr. Phys. Atmos., 52, 287-305.

- T. C. Yeh, J. S. Malkus, and N. E. LaSeur, 1951: The northeast trade of the Pacific Ocean. Quart. J. Roy. Meteor. Soc., 77, 589626.

Rust, W. D., D. R. MacGorman, and R. T. Arnold, 1981: Positive cloud-to-ground lightning flashes in severe storms. Geophys. Res. Lett., 8, 791-794.

Schwartz, B. E., and C. A. Doswell, 1991: North American rawinsonde observations: Problems, concerns, and a call to action. Bull. Amer. Meteor. Soc., 72, 1885-1896.

Simpson, J. E., 1987: Gravity Currents: In the Environment and the Laboratory. Ellis Horwood, $244 \mathrm{pp}$.

Stommel, H., 1947: Entrainment of air into a cumulus cloud. $J$. Meteor., 4, 91-94.

Stolzenburg, M., 1990: Characteristics of the bipolar pattern of lightning locations observed in 1988 thunderstorms. Bull. Amer. Meteor. Soc., 71, 1331-1338.

Wade, C. G., 1991: Improved low humidity measurements using the radiosonde hygristor. Preprints, Seventh Symp. Meteorological Observations and Instrumentation, New Orleans, Amer. Meteor. Soc., 285-290. 